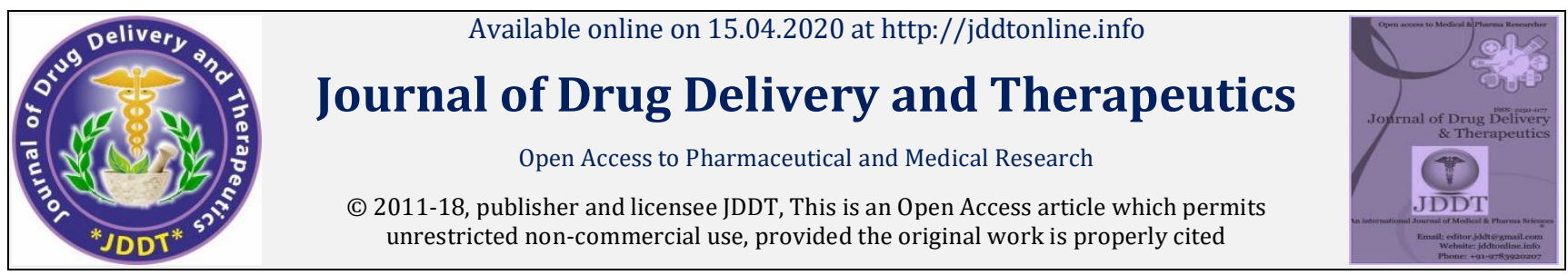

Open Access

Research Article

\title{
Polyphenolic content, Antioxidant and Anti-inflammatory activities of Melon (Cucumis melo L. var. inodorus) Seeds
}

\author{
Amel Bouaziz*, Saliha Djidel , Assia Bentaher and Seddik Khennouf \\ Laboratory of Phytotherapy Applied to Chronic Diseases, Department of Biology and Animal Physiology, Faculty of Nature and Life Sciences, \\ University Ferhat Abbas Setif 1, 19000, Algeria
}

\begin{abstract}
The aim of this study was to estimate the content of polyphenols, flavonoids and tannins compounds and to evaluate the antioxidant activity and the in vitro anti-inflammatory of the ethanolic extract of melon (Cucumis melo L. var inodorus) seeds. The Folin-Ciocalteau and $\mathrm{AlCl}_{3}$ methods were applied in order to quantify the polyphenolic and flavonoids contents, respectively. However, DPPH and $\beta$-carotene bleaching method were applied to evaluate the in vitro antioxidant activity. The polyphenolic and flavonoids contents of seeds extract were found to be $37,10 \pm 1,11 \mathrm{mg} \mathrm{GAE} / \mathrm{g}$ of dry extract and $0,43 \pm 0,27 \mathrm{mg} \mathrm{QE} / \mathrm{g}$ of dry extract, respectively. Whereas the amount of tannins was $48,30 \pm$ $0,90 \mathrm{mg}$ TAE$/ \mathrm{g}$ of dry extract. The scavenger effect of seeds extract against DPPH radicals showed $\mathrm{IC}_{50}$ value of $4,13 \pm 0,07 \mathrm{mg} / \mathrm{ml}$. The $\beta$ carotene bleaching assay indicated a strong inhibition percentage of the lipid peroxidation with value of $69,47 \%$. The in vitro anti-inflammatory activity was evaluated using the inhibition of proteins denaturation revealed that the seeds extract had a moderate anti-inflammatory activity which is estimated at $49,09 \%$ compared to the aspirin $(97,73 \%)$ at $1 \mathrm{mg} / \mathrm{ml}$. Finally, melon seeds may be considered as a promising source of natural antioxidants which possess remarkable therapeutic action as inflammatory activity and may serve as food ingredients.
\end{abstract}

Keywords: Cucumis melo var. inodorus, Polyphenols, Flavonoids, Tannins, Oxidative stress, Anti-inflammatory activity.

Article Info: Received 25 Jan 2020; Review Completed 21 March 2020; Accepted 28 March 2020; Available online 15 April 2020

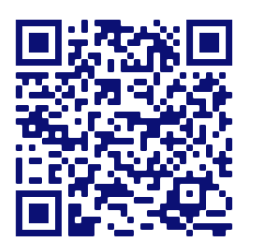

\section{Cite this article as:}

Bouaziz A, Djidel S, Bentaher A, Khennouf S, Polyphenolic content, Antioxidant and Anti-inflammatory activities of Melon (Cucumis Melo L. var. inodorus) Seeds, Journal of Drug Delivery and Therapeutics. 2020; 10(2-s):22-26 http://dx.doi.org/10.22270/jddt.v10i2-s.4022

\section{*Address for Correspondence:}

Amel Bouaziz, Laboratory of Phytotherapy Applied to Chronic Diseases, Department of Biology and Animal Physiology, Faculty of Nature and Life Sciences, University Ferhat Abbas Setif 1, 19000, Algeria

\section{INTRODUCTION}

Oxidative stress is defined as an imbalance between the production of free radicals and the ability of the organism to counteract or detoxify their harmful effects through neutralization by antioxidants. As free radicals are very reactive species, their overproduction during oxidative stress can cause damage to all biological macromolecules, such as DNA, proteins and lipids, thus leading to cell damage and subsequently, to the manifestation of pathological conditions as cardiovascular diseases, diabetes and inflammatory diseases [1]. Antioxidants are secondary molecules or metabolites that act as ROS scavenger and activator of cellular antioxidative enzymes to prevent the damages induced by ROS in biological system. Hence, naturally occurring antioxidants from plant polyphenols are getting more attention in terms of practical usage as safe and potent bioactive compounds[2].

Fruits and vegetables are important source of antioxidants such as phenolic acid, flavonoids, and cartonoids. These compounds are important functional food. Fruits can be ISSN: 2250-1177 considered as natural materials to prevent human from various pathologies as they may help to reduce the risk of many age related degenerative diseases through the elimination of free radicals[3].

Melon (Cucumis melo L.) belonging to the Cucurbitaceae family and it is one of the most consumed fruits worldwide due to its pleasant flavour and nutritional value but its residue, peel and seeds, is commonly discarded [4]. Melon pulp is rich in important vitamins, phytoene, $\beta$-carotene, and 5-methyltetrahydrofolic acid [5] and it possesses high antioxidant and anti-inflammatory properties [6] . However, there is a lack of information regarding the antioxidant and the pharmacological assessment of melon seeds which are generally thrown away which might be considered an economical and nutritional loss. Thus, the main objectives of this study were to determine the phenolic, antioxidant and antiinflammatoty activities of ethanolic extract of melon (Cucumis melo L. var inodorus) seeds from Algeria. 


\section{MATERIALS AND METHODS}

\section{Collection of plant material and preparation of extract}

Fresh melon was purchased from the market in Setif region (Northeastern of Algeria) and its seeds were removed and washed with distilled water and completely dried. Then, the dried seeds were crushed and grinded into powder. The extraction of phenolic compounds was carried out according to method used by Markham [7], Briefly, $50 \mathrm{~g}$ of powdered sample was mixed with $500 \mathrm{ml}$ of ethanol-water mixture $(85: 15, \mathrm{v} / \mathrm{v})$ and kept at room temperature for 5 days to allow maximum extraction of bioactive molecules. The resulting solution was then filtered and the supernatant was evaporated using vacuum rotary evaporator at $40^{\circ} \mathrm{C}$ to obtain crude ethanolic extract.

\section{Determination of total polyphenols content}

The total polyphenols content was determined by the FolinCiocalteu method as described by Li et al. [8] with slight modification. In brief, $0.1 \mathrm{ml}$ of seeds extract was mixed with $0.5 \mathrm{ml}$ of Folin-Ciocalteu reagent (diluted 10 times). After 4 min, $0.4 \mathrm{ml}$ of $7.5 \%$ sodium carbonate $\left(\mathrm{Na}_{2} \mathrm{CO}_{3}\right)$ solution was added. The final mixture was shaken and then incubated for 90 min in dark at room temperature. The absorbance of all samples was measured at $760 \mathrm{~nm}$ and the results are expressed in milligrams of gallic acid equivalents per gram dried weight (mg GAE/g DW).

\section{Determination of total flavonoids content}

The total flavonoids content of each extract was determined by a colorimetric method as described by Bahorun et al. [9]. $1 \mathrm{ml}$ of seeds extract was mixed with $1 \mathrm{ml}$ of aluminium chloride $\left(\mathrm{AlCl}_{3}\right)$ solution (2\%) and allowed to stand for 10 min. Absorbance of the mixture was then determined at 430 $n m$ versus prepared methanol blank. Results were expressed as quercetin equivalent per gram dried weight $(\mathrm{mg} \mathrm{QE} / \mathrm{g}$ DW).

\section{Determination of tannins content}

The capacity to precipitate haemoglobin was determined by using bovine fresh blood according to the method described by Gharzouli et al. [10] . Briefly, a volume of seeds extract was mixed with an equal volume of hemolysed bovine blood (absorbance $=1.6$ ). After $20 \mathrm{~min}$, the mixture was centrifuged at $4000 \mathrm{rpm}$ for $10 \mathrm{~min}$, and the absorbance of the supernatant was measured at $756 \mathrm{~nm}$. Results were expressed as mg equivalent tannic acid per gram dried weight (mg TAE/g DW).

\section{Evaluation of antioxidant activity}

\section{DPPH radical scavenging assay}

Free radical scavenging activity against 2, 2-diphenyl- 1picrylhydrazyl (DPPH) radical was measured using the method described by Hanato et al. [11]. $1 \mathrm{ml}$ of different dilutions of seeds extract were added to $0.5 \mathrm{ml}$ of a $0.004 \%$ methanolic solution of DPPH. After $30 \mathrm{~min}$ at room temperature, the absorbance was measured at $517 \mathrm{~nm}$. BHT was used as standard. Inhibition of free radical DPPH in percent (I \%) was calculated in following way:

\section{$I \%=100$ (A control - A sample) $/$ A control}

Where A control is the absorbance of the blank solution (containing all reagents except the test compound), and A sample is the absorbance in the presence of the test compound.

\section{$\beta$-Carotene Bleaching Assay}

In this test, the antioxidant capacity of the seeds extract is determined according to the method of Dapkevicius et al. [12]. Briefly, A stock solution of $\beta$-carotene-linoleic acid mixture was prepared as follows: $0.5 \mathrm{mg} \beta$-carotene was dissolved in $1 \mathrm{ml}$ of chloroform and $25 \mu \mathrm{l}$ linoleic acid and $200 \mathrm{mg}$ Tween 40. Chloroform was completely evaporated, and then, $100 \mathrm{ml}$ distilled water saturated with oxygen (30 $\min , 100 \mathrm{ml} / \mathrm{min}$ ) were added with vigorous shaking. 2500 $\mu \mathrm{l}$ of this reaction mixture were dispensed into test tube and $350 \mu \mathrm{l}$ of seeds extract, prepared at $2 \mathrm{mg} / \mathrm{ml}$ concentrations, were added and the emulsion system was incubated for $48 \mathrm{~h}$ at room temperature. The same procedure was repeated with synthetic antioxidant BHT as positive control, and blanks ( $\mathrm{MeOH}$ and $\mathrm{H}_{2} \mathrm{O}$ ). The absorbance of the mixture was measured at $490 \mathrm{~nm}$ after; 0, 1, 2, 4, 6 and 24 hour. The antioxidant activity (AA) was measured in terms of successful bleaching of $\beta$-carotene by using the following equation: $\mathbf{A A} \%=$ A sample $/$ A BHT $\times 100$.

A sample: Absorbance in the presence of the extract; A BHT: Absorbance in the presence of positive control BHT.

\section{In vitro anti-inflammatory activity}

The anti- inflammatory activity of melon extract was studied using inhibition of albumin denaturation technique which was studied according to Akkouche et al. [13]with minor modifications. After washing and cleaning of eggs, they are carefully broken and the white and yolk separated. The volume of egg white is measured using a test-tube and then adjusted with the buffer solution Tris-HCl (20 mM pH 6.8) to obtain a dilution solution of $1: 100$. A gentle stirring for 10 minutes is performed on the egg solution followed by filtration with a strip agase. Identical volumes were transferred to tubes then the melon seeds extract and aspirin were added and the tubes were incubated at $74^{\circ} \mathrm{C}$ for $15 \mathrm{~min}$. After cooling, the absorbance was measured at $650 \mathrm{~nm}$. The percentage inhibition of protein denaturation was calculated as follows:

\section{$\mathrm{I} \%=($ Abs Control - Abs sample $) /$ Abs Control $\times 100$}

\section{Statistical Analyses}

The results are expressed as the mean \pm standard deviation. One-way analysis of variance (ANOVA) followed by the Tukey test was performed to assess differences between groups. Differences were considered significant at $\mathrm{p}<0.05$.

\section{RESULTS AND DISCUSSION}

\section{Total polyphenols, flavonoids and tannins contents}

Phenolics, tannins and flavonoids are secondary plant metabolites that can be involved in complex system of antioxidant defense through free radical scavenging activity, chelation of transition metals and inhibition of prooxidative enzymes. They play also beneficial role in in the treatment of many ailments such as inflammatory disorders, cardiovascular diseases, cancer and diabetes which occur due to the deregulation of free radicals generation [14].

In this study, The total phenolic and flavonoids contents in melon seeds ethanolic extract were found to be $37,10 \pm$ $1,11 \mathrm{mg} \mathrm{GAE} / \mathrm{g}$ and $0,43 \pm 0,27 \mathrm{mg} \mathrm{QE} / \mathrm{g}$ extract. Whereas the tannins content was $48,30 \pm 0,90 \mathrm{mg}$ TAE/g extract. Azeb et al. [5] have identified nine phenolic compounds in seeds methanolic extract using (HPLC-DAD) and this finding can explain the richness of seeds ethanolic extract in this study by polyphenols. 


\section{Antioxidant activity evaluation}

\section{DPPH radical scavenging activity}

The model of scavenging the stable DPPH radical is a widely used method to evaluate the free radical scavenging ability of several natural compounds. DPPH is a stable nitrogencentered free radical whose color changes from violet to yellow upon reduction by either the process of hydrogen or electron donation. Substances which are able to perform this reaction can be considered as antioxidants and therefore radical scavengers[15].
In this study, a significant decrease in the amount of DPPH radical was observed due to the scavenging ability of seeds extract and standard. The seeds ethanolic extract exhibited a higher scavenging effect $\left(\mathrm{IC}_{50}=4,13 \pm 0.07 \mathrm{mg} / \mathrm{ml}\right.$ ) that remains lower than that of standard (BHT) with an IC 50 of $0.01 \pm 0,001 \mathrm{mg} / \mathrm{ml}$. Otherwise, seeds extract scavenge DPPH radical in dose dependent manner with inhibition being higher than $97 \%$ at $8 \mathrm{mg} / \mathrm{ml}$ (Figure1).This strong DPPH scavenging effect could be attributed to the presence of polyphenols which can serve as free radical scavenger and hydrogen donner.

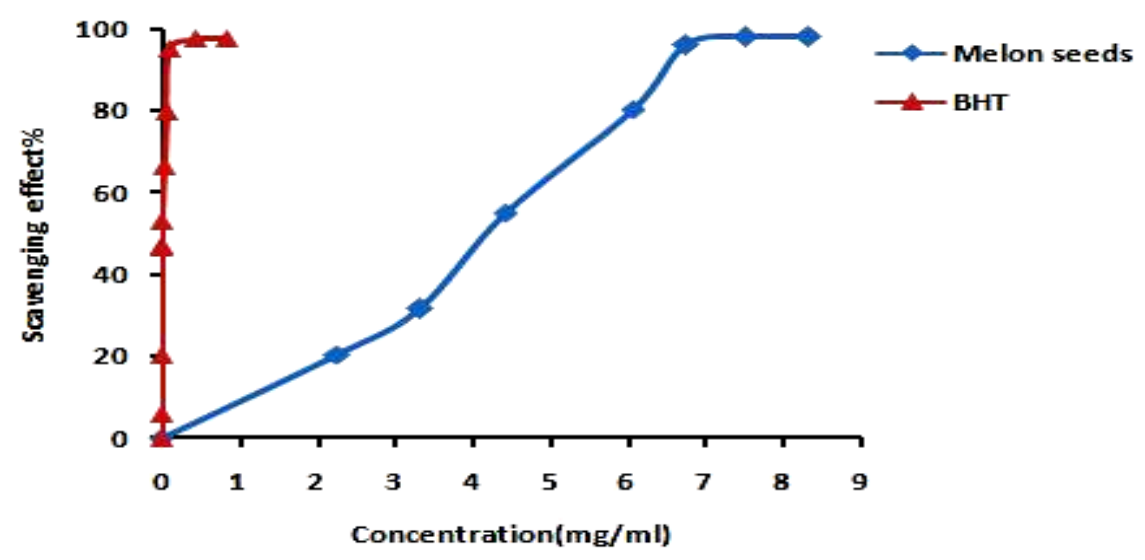

Figure 1: DPPH radical scavenging activity of seeds ethanolic extract from C. melo var inodorus

\section{$\beta$-Carotene/linoleic acid bleaching assay}

$\beta$-carotene bleaching assay is based on the discoloration of $\beta$ - carotene owing to its reaction with linoleic acid-generated free radicals in an emulsion system. In the presence of an antioxidant compound, this degradation process is prevented. It also reflects the ability to inhibit the lipid peroxidation in vitro [16].

As seen in Figure 2, seeds ethanolic extract showed a marked antioxidant activity $(69,47 \pm 0.58 \%)$ when compared to the synthetic antioxidant BHT which had lipid peroxidation inhibition percentage of $97,61 \pm 0.27 \%$ at the same concentration $(2 \mathrm{mg} / \mathrm{ml})$.

The obtained results may be due to the presence of polyphenols and flavonoids witch have the principal contribution to the antioxidant capacity of seeds extract. In fact, literature showed that good correlation was found between antioxidant activity and the content of polyphenols and flavonoids contents [17].

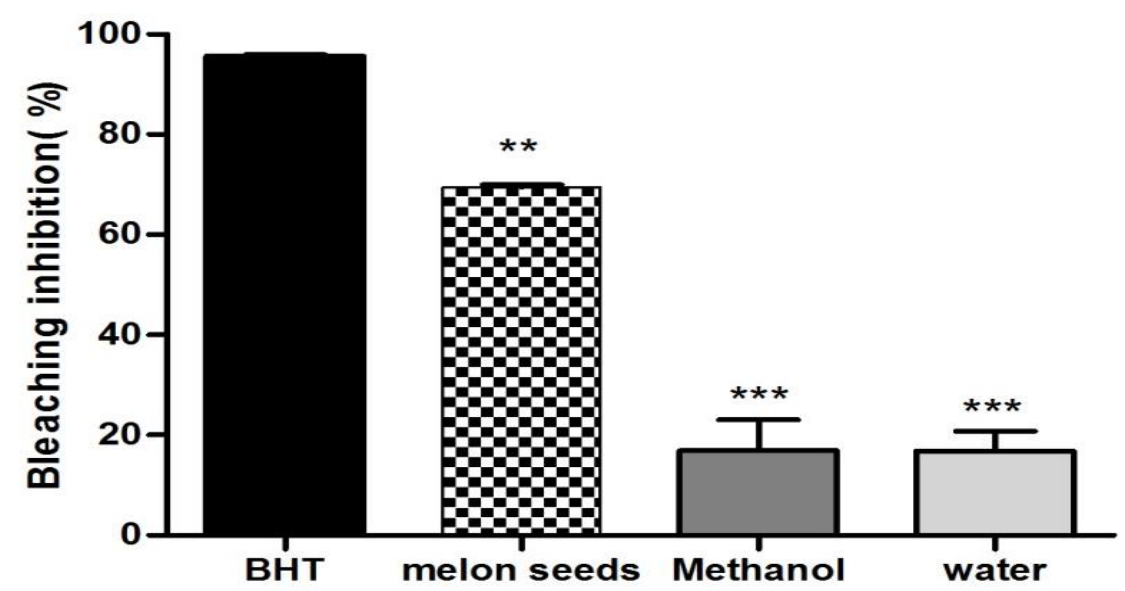

Figure 2: Antioxidant activities of seeds ethanolic extract from C. melo var inodorus $(2 \mathrm{mg} / \mathrm{ml}$ at 24 hours of incubation) measured by $\beta$-carotene bleaching method. BHT was used as reference antioxidant. Values are means $\pm \operatorname{SD}\left({ }^{* *} \mathrm{p}<0.01 ;{ }^{* * *} \mathrm{p}<\right.$ 0.001) compared to BHT as standard. 


\section{Inhibition of proteins denaturation}

In vitro anti-inflammatory effect of seeds of C. melo var inodorus was evaluated for the first time using denaturation of albumin test. The result of the anti-inflammatory activity in vitro showed that the ethanolic extract of melon seeds was able to inhibit protein denaturation in a concentration- dependent manner (Figure 3). The inhibition percentage of protein denaturation of this extract was within the range from $15.23 . \%$ to $49.09 \%$ at the concentration range of 0.125 to $1 \mathrm{mg} / \mathrm{ml}$. Also, Aspirin which is type of NSAIDs was used as reference drug exhibited concentration dependent inhibition of protein denaturation with higher inhibition capacity of $97.73 \%$ at concentration of $1 \mathrm{mg} / \mathrm{ml}$.

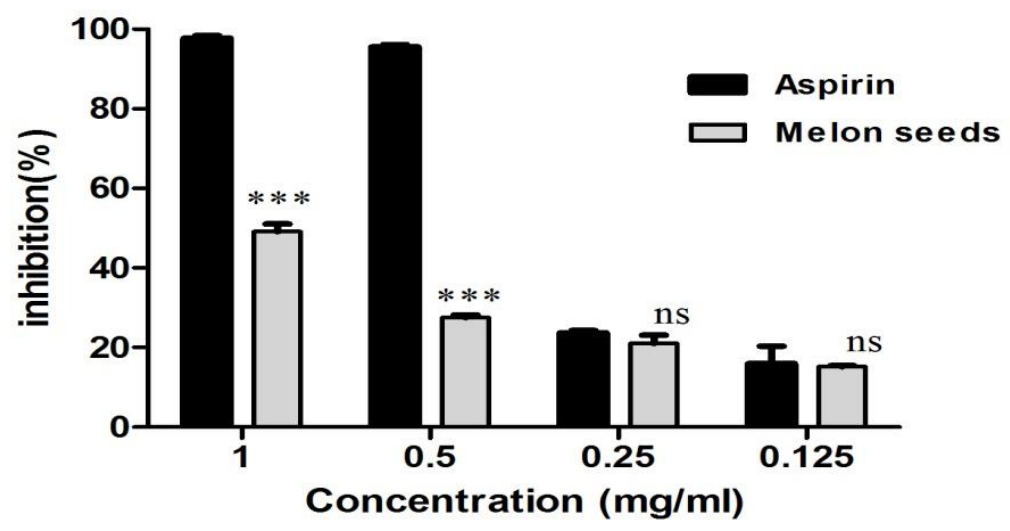

Figure 3: Protein denaturation inhibition power of seeds ethanolic extract from C. melo var inodorus . Aspirin was used as reference drug. Values are means $\pm \mathrm{SD}\left(\mathrm{ns} \mathrm{p}<0.05 ;{ }^{* *} \mathrm{p}<0.01\right)$ compared to aspirin

Proteins denaturation is a process in which proteins lose their secondary and tertiary structure through the alteration of electrostatic hydrogen, hydrophobic and disulfide bonding leading to the production of autoantigens in the inflammatory diseases as rheumatic arthritis $[18,19]$ . So, natural products that can prevent protein denaturation would be possible candidate for anti-inflammatory drug development. NSAIDs prevent inflammation by blocking the cyclooxygenase enzyme activity. However, these drugs cause side effects of ulceration, hemorrhage, perforation and obstruction [20, 21]. Hence, there is a need for new antiinflammatory drugs with lower potential for adverse effects, such as the plant-based substances which are considered to be relatively safe.

In this study, the standard drug (Aspirin) is approximately 2 times more potent than the crude seeds extract at $1 \mathrm{mg} / \mathrm{ml}$. Hence it is obvious, that if this crude extract is purified, the pharmacological activity will increase significantly and might even match those of the standard drug. The high amount of polyphenols present in the extract may be responsible for the anti-inflammatory activity of this extract. Many studies have shown that many flavonoids and related polyphenols contribute significantly to the antiinflammatory activities exerted by many plants [22].

\section{CONCLUSION}

The results of this study showed that the melon seeds ethanolic extract has a high content of total phenolic compounds which can contribute to the field of functional foods, as it has provided results for a potential new use of melon seeds, in particular its role in the prevention of antiinflammatory diseases and oxidative stress related diseases . Further studies are need on the seed extracts to find the exact mechanism of action for its pharmological properties over its anti-inflammatory effects.

\section{REFERENCES}

1. Goutzourelas $\mathrm{N}$, stagos D, spanidis $\mathrm{Y}$, liosi $\mathrm{M}$, apostolou A, priftis A, haroutounian S, spandidos D A, tsatsakis A M and Kouretas D, Polyphenolic composition of grape stem extracts affects antioxidant activity in endothelial and muscle cell, Molecular Medicine reports, 2015; 12: 5846-5856.

2. Rahman MM, Hossain MS, Mostofa M G, Ali Khan M, Ali R, Mosaddik A, Sadik M G, Khurshid Alam A, Evaluation of anti-ROS and anticancer properties of Tabebuia pallida $\mathrm{L}$. Leave. Clinical Phytoscience,2019; 5:17, 1389.

3. Singh J P, Kaur A, Singh N, Nim L, Shevkani K, Kaur H, Arora DS, In vitro antioxidant and antimicrobial properties of jambolan (Syzygium cumini) fruit polyphenols. LWT-Food Science and Technology, 2016; 65: 1025-1030.

4. Rolim P M , Fidelis G P , Padilha, C E A, Santos E S, Rocha H A $O$, Macedo $G R$, Phenolic profile and antioxidant activity from peels and seeds of melon (Cucumis melo L. var. reticulatus) and their antiproliferative effect in cancer cells. Brazilian Journal of Medical and Biological Research, 2018; 51(4): 6069

5. Zeb A, Phenolic Profile and Antioxidant Activity of Melon (Cucumis Melo L.) Seeds from Pakistan, foods, 2016; 5:67-73.

6. Ismail $\mathrm{H} \mathrm{I}$, Chan $\mathrm{KW}$, Mariod $\mathrm{AA}$, Ismail $\mathrm{M}$, Phenolic content and antioxidant activity of cantaloupe (Cucumis melo) methanolic extracts, Food Chemistry, 2010;119: 643-647.

7. Markham K R. Techniques of Flavonoid Identification, London Academic Press, Chap. 1 and 2, 1982, p. 113.

8. Li HB, Cheng KW, Wong CC, Fan KW, Chen F, Jiang Y, Evaluation of antioxidant capacity and total phenolic content of different fractions of selected microalgae, Food chem,2007; $102:$ 771-776.

9. Bahorun T, Gressier B, Trotin F, Brunet C, Dine T, Luyckx , Oxygen species scavenging activity of phenolic extracts from hawthorn fresh plant organs and pharmaceutical preparations. Arzneimittelforschung, 1996; 46 : 1086-1089.

10. Gharzouli K, Khennouf S, Amira S, Gharzouli A, Effects of aqueous extracts from Quercus ilex L. root bark, Punica granatum L. fruit peel and Artemisia herba-alba Asso leaves on ethanol-induced gastric damage in rats. Phytother Res, 1999; 13: 42-45.

11. Hanato $T$, Kagawa $H$, Yasuhara $T$, Okuda $T$, Two new flavonoids and other constituents in licorice root: Their relative astringency and radical scavenging effects, Chemical \& Pharmaceutical Bulletin, 1998; 2090-2097.

12. Dapkevicius A, Venskutonis R, Van Beek T A, Linssen JPH. Antioxidant activity of extracts obtained by different isolation procedures from some aromatic herbs grown in Lithuania. $J$ Sci Food Agric 1998; 77: 140-146.

13. Akkouche Z, Aissat L, Madani K, Effect of Heat on Egg White Proteins. International Conference on Applied Life Sciences, 2012; 407-413. 
14. Saoudi S, Khennouf $\mathrm{S}$, Mayouf $\mathrm{N}$, Identification and quantification of fruit phenolic compounds of Malus communis, Journal of Drug Delivery \& Therapeutics, 2019; 9(6-s):1-4.

15. Bouaziz A, Khennouf $S$, Abdalla S, Djidel S, Abu Zarga M, Bentahar A, Baghiani A, dahamna S, Amira S, Phytochemical analysis, antioxidant activity and hypotensive effect of Algerian azarole (Crataegus azarolus L.) leaves extracts, Res J Pharm Biol Chem Sci,2014; 5 (2) :286-305.

16. Baghiani A, Boumerfeg S, Adjadj M, Ameni D, Djermouni M, Khelifi-Touhami F, Charef N, Khennouf S, Arrar L, Antioxidants, free radicals scavenging and xanthine oxidase inhibitory potentials of Ajuga iva L. extracts. Free Radic Antioxid J, 2011; 1: 21-30.

17. Aouachriaa S, Boumerfeg S, Benslama A, Benbacha F, Guemmeza T, Khennouf S, Arrar L, Baghiani A, Acute, subacute toxicity and antioxidant activities (in vitro and in vivo) of Reichardia picroide crude extract, Journal of Ethnopharmacology, 208;2017: 105-116.
18. Banerjee S, Chanda A, Adhikari A, Das AK, and Biswas S, Evaluation of Phytochemical Screening and Anti Inflammatory Activity of Leaves and Stem of Mikania scandens (L.) Wild, Ann Med Health Sci Res, 2014; 4(4): 532-536.

19. Aichour R, Benzidane N, Arrar L, Charef N and Baghiani A, Hepatoprotective and Anti-inflammatory Activities of Algerian Capparis spinosa L, Annual Research \& Review in Biology, 2018; 25(3): 1-12.

20. Sangeetha G, Vidhya R, In vitro anti-inflammatory activity of different parts of Pedalium murex (L.), Int J Herb Med, 2016;4:31-6.

21. Sostres C, Gargallo C J, Arroyo M T, Lanas A, Adverse effects of non-steroidal anti-inflammatory drugs (NSAIDs, aspirin and coxibs) on upper gastrointestinal tract. Best Pract Res Clin Gastroenterol, 2010; 24:121-32.

22. Marrassini C, Peralta I, Anesini C, Comparative study of the polyphenol content-related anti-inflammatory and antioxidant activities of two Urera aurantiaca specimens from different geographical areas, Chin Med, 2018; 13: 22. 